\title{
Guerilla Eats and Bicycle Espresso. The Changing Contemporary Food Culture of Urban Helsinki
}

\author{
Mika Savela \\ Canadian Centre for Architecture, Montréal, Canada \\ mika@mikasavela.com
}

\begin{abstract}
The Finnish urban food culture traditionally differs from continental European traditions.

Restaurants, bistros, eateries or street food have never been similarly integral to everyday life as perhaps in many world cities. In Helsinki, the relatively young urban history, strict regulations on the sales of food and alcohol, diminishing food traditions, modernist urban planning and strong public control of the cityscape, have all contributed in limitations regarding urban food culture. However, since early 2000s, demand for more diverse urban food and restaurant culture has surged among the younger generations along with a rediscovery of domestic culinary traditions. Public debates and activism concerning the rigid bureaucracy related to food culture have resulted in culinary culture strategies and re-considering food as part of the urban culture, contemporary practices, and development of urban districts. For Helsinki, the relative success of these changes has been integrally connected to citizen campaigns and information distributed in social media, as well as previous stagnation of both urban food culture and public policies. The paper looks into small-scale citizen-led cases of urban food culture development in Helsinki over the past years, with focus on the story of "Restaurant Day", its origins as an illegally organized temporary event turned into a global phenomenon - before its obliteration in a post-temporary reality. The cases are set against histories of Finnish food culture and current viewpoints on foodways as generators of urban groups and new identities. By reviewing the handling of contemporary Helsinki-based food practices, especially in media and public documents, the paper evaluates how urban food culture and the sense of ownership in public space and the city at large have activated communities and created actual policy changes.
\end{abstract}

Keywords: urban culture; food; Helsinki; events; public space; urban foodways; Restaurant Day.

\section{To cite this article:}

Savela, M. (2016). Guerilla Eats and Bicycle Espresso. The Changing Contemporary Food Culture of Urban Helsinki. The Journal of Public Space, I(I), 95-I I2, DOI: I0.5204/jps.vlil.I3

This article has been peer-reviewed and accepted for publication in The Journal of Public Space. Please see the Editorial Policies under the 'About' section of the journal website for further information.

\section{(i) \$

This work is licensed under a Creative Commons Attribution - Non Commercial 4.0 International License. https://creativecommons.org/licenses/by-nc/4.0/ 


\section{Introduction}

The image, identity, history, and soul of many American cities can be captured in the foods that have come to define their unique culinary landscapes. It is almost impossible to envision these cities without the sights, smells, sounds, textures, and tastes of the edible environment overtaking the individual: the charred-molasses barbecue of Kansas City, the heft of a golden Chicago pizza, the feel and peel of a spicy New Orleans crawfish boil. Perhaps nowhere else in the United States is this more the case than in New York.

The above quote from the preface of Gastropolis (Hauck-Lawson and Deutsch, 20I0), a book on New York and the American urban food culture, exemplifies the starting point of this overview of Helsinki's contemporary culinary setting in multiple ways. Firstly, it serves to remind of the sheer difficulty in finding similar popular, not to mention global quotes related to Helsinki. Secondly, whatever might constitute as Finnish food culture, does not traditionally stem from cities, or a particular Finnish urban culture or history, but instead from a rural past and its later idealizations. Thirdly, as the quote speaks volumes of the power of food in capturing the soul and essence of cities in a popular manner, it perhaps to an extent validates the attempt of this paper in tracing shifts in the food culture related to what could be described as a larger urban soul-searching of the Finnish capital in the recent years. Helsinki, after all, is one of the still growing, young metropolitan regions in Europe (Laakso, 2012), and its cultures and urban identities are still in a constant flux. In general, the theme of food in cities or urban foodways has surfaced into the mainstream culture in several ways. While definitely a global issue, food has also become central to current lifestyles, especially in the Western world. Slow food, supper clubs, urban agriculture, local production, farmers' markets, food waste and street food have all become increasingly vibrant practices - with much emphasis on the pleasure of food as part of daily life - contributing into the role of food in new urban identities. (Levi, 2015: 233). Origins of food, its production, aesthetics, authenticity, healthiness, smartness, traditional values and even the related social networks and contexts have played into the current changes in the contemporary urban food culture in many cities globally.

Furthermore, food has become central in creative urban economies, foodism and even spatial practices, turning into forms of community participation and "DIY urbanisms". Over the recent years, such themes have been increasingly covered in research as well as by several design practices that have begun to work with the theme of food. (e.g. Zeiger, 20II, or Miazzo \& Minkjan, 2013; Taussig, 2016) However, as interest in food has started to display public and urban dimensions, various policies and the politics of food have become increasingly urgent, as is the case with Helsinki.

While the focus of this paper is in contemporary urban developments related to food in Helsinki, elements of the city's history as well as traditional Finnish habits and practices should be first understood, as they offer insight into the currently undergoing cultural changes. The paper attempts firstly to specify, why contemporary urban food culture has had such a fertile ground in Helsinki, and how the urban way of life in Finland in general has differed from a more general European or Western contexts. Here, the concepts and terminology regarding foodways as urban culture and heritage are also discussed.

Another history the paper touches upon, relates to the strong regulatory and bureaucratic history regarding Finnish restaurant culture, food safety, alcohol serving and consumption at various levels of government. These topics are vital to understanding the currently 
popular de-regulation rhetoric concerning urban food culture of Helsinki, as so many of the recent developments have resulted in historically unprecedented public resistance towards food-related guidelines. At the same time, the modernist origins of such sanitary regulations, state control and nation-building ideals still form the basis of Finnish urban planning and the welfare state project. As such, changes in urban food culture seem to be both signaling and catalyzing larger changes that are taking place in urban Finland. Against these histories and themes, the paper continues to look into case studies of recent urban food culture developments in Helsinki over the past years, with focus on the relative success story of Ravintolapäivä (Restaurant Day), which started in $201 \mathrm{I}$ as a oneoff protest event, eventually turning into a prize-winning globally celebrated food festival, utilizing design and technology as effective means for networking and urban participation, and also manifesting as spatial urban interventions. Other recent cases, such as the Camionette café truck or other mobile installments have brought the issues of aesthetics, use and control of Helsinki streetscape under a new kind of public consideration. In addition, entirely new events, institutions and planning strategies are spreading and signifying that these changes have not yet reached their saturation point among the great public and that new forms of creativity, culture and economic activities are still created around the theme of food and the city.

Finally, the paper proceeds to evaluate if such described developments are in effect part of a larger cultural shift in urban Helsinki - and how the city is currently positioned in the viewing of urban foodways, and "food and cities" as a thematic. A further consideration is the dual role of food-related practices in contemporary Helsinki as a non-confrontational "training ground" for building and expressing new and more diverse urban identities, also in relation to people's right to the city, and the design of public services and urban governance.

\section{Food as Urban Culture}

While the general understanding of "food as culture" is almost universal, the relationship of food and the city has not become such a socially or culturally nuanced topic until recently. With ever-increasing global urbanization, the everyday connection of food and urban people has also received more critical dimensions. Characterized as urban foodways, the varied patterns of food in the city have been defined readable as forms of human communication and intangible cultural heritage, where issues like identity, race, ethnicity, gender, class, ideology and social relations have an impact. (Lum \& de Ferrière le Vayer, $2016,1-2)$ While urban research related to foodways has relatively often focused on cultural heritage reinforcing ethnic identities in multicultural settings (Brulotte \& Di Giovinc, 20I4, 3), considering food as heritage is known to have socio-cultural impacts that in turn generate all kinds of groupings and identities. (lbid., 18) Of course, what such readings suggest is a much more varied study of urban food culture, far beyond the history of restaurants or elements of the local cuisine. In these aspects, critical considerations or updated views on Finnish urban food culture still remain few in numbers.

In the Finnish language, the word ruokakulttuuri (food culture) is commonly used as a way to describe heritage, but as such it lacks urban connotations, referring more plainly to domestic traditions and habits related to food. Compared to the idea of urban foodways, ruokakulttuuri remains tied to a rural or semi-urbanized Finnish landscape, where 
celebrated food items such as cloudberries, venison, wild salmon or bear meat have almost nothing to do with everyday urban lifestyles or living traditions, serving more as markers of a claimed identity or self-exoticization. (Kolbe, 2005) In fact, if studied as foodways, the heritage suggested today by ruokakulttuuri can be seen as a rather problematic collection of different cultural, historical and ethnic varieties, served as a single, national culture of food. On the other hand, due to the exact constructed and preserved homogeneity of modern Finnish society and its relative isolation, the culture of food in Finland has in turn been very homogenous, making it impossible to study as an urban melting pot.

Yet, the traditional narrow definitions of ruokakulttuuri have become increasingly obvious in the urban context. In the past decades, Helsinki has continued to grow, as well as becoming increasingly diverse. (Erjansola \& Haukkavuo, 2016) Here, it should be accentuated, that by European standards this late and somewhat subdued development towards globalization and multi-culturalism is entirely different from many world cities, or even neighbouring capitals. Thus, for Helsinki, as projected by the definitions of urban foodways, similar to many other urban dynamic forces, it could be said that food has slowly started to manifest itself in previously non-existing social and material ways, forming new group identities and becoming a site of intergroup communication. (Lum \& de Ferrière le Vayer, 2016, 6) Indeed, the growth of urban diversity along with globalized urban lifestyles could be seen as one of the special reasons as to why changes in the urban makings of Helsinki have recently manifested themselves especially in relation to food.

\section{Brief Urban Food History of Helsinki}

Kaupunki on muuttunut / mutta ei järin paljon / muistamme sen värin / joka oli harmaampi / silloin ei ollut yhtään eurooppalaista vaateliikettä / olutta oli vain ruokailijoille / koko paikka muistutti Neuvostoliittoa

The city has changed / but not that much / we still remember its color / far more gray / without a single European fashion chain / beer was only served with food / it was just like Soviet Union

Excerpt with translation from “Helsinki” (1996) a pop song by Ultra Bra. Lyrics by Anni Sinnemäki

To understand exactly why contemporary urban lifestyles and public events have driven changes in practices related to food in today's time, the history of urban Helsinki and the history of its food culture should be explained further. For instance, at a glance, visual historical evidence like $19^{\text {th }}$ century photos of Helsinki will set a scene similar to almost any Western European small city, equipped with restaurants, bakeries, cafes and park pavilions. The turn-of-the-century food culture appears as "urban" as it probably ever was at the time. However, the pre-WWI Helsinki, is in many ways not a reflection of the mono-cultural narrative that Finland as a nation would built for itself in the modern era. Instead, urban life in the $19^{\text {th }}$ and early $20^{\text {th }}$ century Helsinki was entirely dependent of one's social class, language, wealth and even nationality. This is why in the context of Helsinki, there exists no direct lineage between historical manifestations of urban food culture, and how the contemporary food scene has come to look like. Instead, these histories should be understood as chapters with certain discontinuation points. 
Helsinki was originally founded as Helsingfors in 1550 off-site from its current location by the order of King Gustav I of Sweden. Intended as a Swedish-ruled rival for burgeoning Hanseatic trading posts like Tallinn, it failed to gain momentum, even struggling to exist for centuries to come. However, in 1748 plans were made for a sea fortress outside of the modern-day Helsinki. During the decades long construction work, the Sveaborg island, destined as a stronghold against Russia, developed into a much larger and vibrant "city" than Helsingfors ever was. Thus, Swedish navy officers, some of who had served abroad in France or England, were the originators for an international urban food culture in Helsinki (Soini, 1963, 240-24I), which at a time, was a mere peripheral "colonial" $18^{\text {th }}$ century township next to a major military installation, with almost no Finnish-speaking (or Finnishidentifying) population - let alone a sense of a Finnish urban culture.

After Finland's 1809 annexation to Russia from Sweden, Helsinki became the capital of the Grand Duchy of Finland in 18/2. The establishment of this brand new centrality in the Baltic region provided opportunities for many European merchants to arrive and set up or expand their businesses in close proximity of bustling St. Petersburg, half-way to Stockholm. (Soini, 1963, 30I) The steady flow of immigrant entrepreneurs produced a cosmopolitan atmosphere, where in fact non-Finnish speakers would be a majority. (Sillanpää, 2002, 254) From this era, the imagery of food in the city, is extremely similar to many European capitals at the time. Hotels, restaurants, Swiss confectioneries and cafés catered to foreign residents or predominantly Swedish-speaking upper classes. Restaurants would also serve especially tourists and travelers, such as Russian aristocracy or visitors to the "far North". At major railroad junctions and visiting destinations, restaurants of high international quality popped up, employing Swedish or German staff and catering French menus. (Ruokatieto, 2016) The common people in Helsinki, would instead buy groceries from the markets, farm, fish or cook in primitive conditions at home, or find a selection of street food vendors and worker's eateries (Nevalainen, 2013).

Throughout industrialization, and especially after Finland's independence from Russia in 1917 and the following civil war, the Finnish-speaking population of Helsinki would grow into a ruling majority. (Erjansola \& Haukkavuo, 2016) Existing urban food culture and restaurants, which could have otherwise continued along their European style existence, with newly urbanized rural Finns possibly adopting previous habits and diets, suffered an almost deadly blow with the alcohol probation law, in place from 1919 until 1932. In hindsight, it has been estimated that the probation era resulted in a somewhat warped role for restaurants in the food culture of Finland, lasting well into the 1990s. (Sillanpää, 2002) Due to the temperance movement's strong social narrative, restaurants became synonymous with social and urban ails. For instance, women could not enter restaurants unless in company of men, suggesting that restaurants were, deep down, sinful establishments. This was not helped by the fact that alcohol was still served in secrecy, distilled at home and smuggled in massive quantities. Restaurants came to be considered places appropriate for moderate celebration or occasional dining, but not belonging to the "real" everyday life, where sober, plain and frugal choices would be the celebrated norm. In fact, well into the $20^{\text {th }}$ century, city life altogether was considered morally inferior to living with nature. (Tani, 1995) As a result, even after the probation era, restaurant sales or consumption of alcohol was dealt with suppressing ideological ethos and fear for societal problems, heavy supervision, and spatial regulation for restaurants - instead of normalizing wine or beer as parts of the food culture. Thus, issues related to alcohol 
consumption became overtly central in the Finnish restaurant culture, turning the restaurant space into a legislative device of regulation. (Sillanpää, 2002, 222)

During WWII, Helsinki experienced a sudden return to a more rural production and dependency of basic farming produce. Food was rationed and store shelves remained empty of import products. Finnish traditions of foraging, fishing and hunting became valued forms of coping with the demands of wartime. On the other hand, the urban relationship with food, continued to be highly divided by wealth, limiting the choices and menus of working class families. Urban poverty with homogenous post-war culture and ideals meant that the urban foodways of Helsinki were in effect limited in diversity and choice.

(Kokkinen, 20I2) In the process of paying massive war compensations to the Soviet Union, good housekeeping and self-sufficiency was valued more than fine dining, snacks or street food, and many Helsinki families would continue to bring back food from the countryside, as Finland as a country was only in the process of urbanization. In such context, few could afford to perceive restaurants or food culture in Helsinki as a particularly urban experience or delight, enabled by the life in the city.

It might sound bold to state, that because of these histories, no classic "Finnish cuisine" truly developed. Food remained tied to local traditions rather than city consumption. The short jump from a predominantly rural existence into modernist urban setting generated a societal narrative. Health and sobriety were encouraged, and "Finnishness" was defined through active relationship with nature and participation in a harmonious and uniform welfare state. Considerations such as restaurant culture were not a shared generational experience. (Sillanpää, 2002, 225) Finnish ruokakulttuuri became a selection of food items that enforced the storyline built the country, its deep connection with nature, unique and pure ingredients. In reality, a loss of traditions, uniformity of society and modernization were already affecting the society, as entire generations started to move to cities, and Helsinki was receiving thousands of new residents per year. Furthermore, a strong consumer cooperative movement gained momentum, and started operating a variety of convenience stores, small eateries, cafés and large scale eateries - while in some ways enforcing food culture as social issue, rather than an urban phenomenon. School meals, too, would contribute towards a Finnish monoculture of food. In their normal lives Helsinki residents of the 1960-70s would retain a modest menu of fish, meat, potatoes, bread and porridges and would only slowly begin to explore food and cooking as part of a lifestyle choice. Slowly throughout the 1980s, larger chain stores would spread to suburbs and some ethnic variety would emerge, and expediting the supply and demand for imported products. Street food would be modestly available in general. Towards the 1990s, the first wholly urban Finnish Helsinkians caught first glimpses of a revival of international restaurant culture, only to be faced with the heaviest economic recession since the 1930s in 1991.

In today's Finland, the market share of the largest consumer cooperative supermarket chain is around $45 \%$, with the main competing group controlling a $35 \%$ share. (Peltoniemi, 2013) Such supermarkets in varied sizes, have today replaced almost every small food stores in Helsinki. The gradual build-up to such an extreme duopoly of food retailers have made the everyday experience of grocery shopping highly uniform all around the country - muddling the differences between an urban and rural selection of food. As supermarkets have overtaken the food sales, traditional food markets of Helsinki have diminished in size, having partly given away to tourism, selling less and less fresh produce for actual day-to- 
day consumption. Together with high taxation on food, labor and services, the general prices for food have stayed relatively high (Eurostat, 2016).

\section{The New Urban Identities}

Finland is a country with thousands of lakes and deep forests. Its northern location makes winters long and summers short. The growing season is also short, and accordingly, when fresh produce, vegetables and fruits are in season, they are prized and served in abundance. Almost every household does some preserving for winter, be it homemade strawberry jam or pickled cucumbers. Most households have freezers where they can store produce from their own garden. (Taimi Previdi.

The Best of Finnish Cooking, 1995, Hippocrene books, New York)

The quote above represents an international-style "cookbook description" of Finnish food culture. While somewhat truthful in describing past Finnish generations and their rural or semi-urban roots, in today's view, talk about "almost every household" making preserved produce from their gardens is mostly inaccurate. This is the result from continued urbanization, where today a significant number of Finns are now second and third generation city people compared to their parents. While Finnish attitudes related to food are undoubtedly changing and following international trends, Helsinki metropolitan area as home to about $30 \%$ of the country's population (City of Helsinki, 20I6) is naturally showing the most visible signs of this development. Thus, new kinds of observations and concerns related to food culture have become more prominent among urban Helsinkians. While positioning high in many life quality and livability rankings compared to the availability of street food in cities such as New York, Helsinki has never truly produced such world-classics as hotdogs or bagels. Having no Chinatown or Little Italy, alongside the comparatively very small number of immigrants - still at around I3\% of population (City of Helsinki, 2016) - has made also the ethnic variety of food scarce. Thus, as urban generations are growing in numbers, the lack of variety and the increasingly voiced comparisons with other cities and countries have resulted in frustration with urban management, decision-making and future planning, seen as slow and bureaucratic processes, discouraging global-style urban experiences. A sentiment shared by many Helsinki residents today, has been that city life in general should come with the perks and benefit of urban density. Popular Facebook discussion groups such as "More City in Helsinki" or blogs like "Urban Finland" and "Helsinki Cyclists" have formed, asking for more value in the urban existence, through better planning, more variety, creativity and sustainability. (Boyer and Hill, 2013) It is in this mixture of calls for quality urban life that also food-centricity and the appearance of urban foodies, food magazines, TV-cooking shows, online culinary maps and recipe blogs have also reached the Finnish cultural mainstream. In the course of a mere generation, global food culture along with a global understanding of the "urban" has opened up for many Helsinki residents in an unprecedented way. New restaurants have been opened by first generations of chefs returning after apprenticeship stints abroad. New corner stores, downstairs bakeries and neo-Finnish local food markets, and organic options have become sought after among younger families who unlike their parents, now prefer to live in predominantly urban districts and demand them to be planned accordingly, and in many ways. (Lindblom \& Mustonen, 2014 \& 2016) 


\section{Urban Movements and New Technology}

...stop treating Internet like it's a different thing and start focusing on what you actually want your society to look like.

Peter Sunde, co-founder of now defunct "The Pirate Bay" file-sharing website. Vice Motherboard, December II, 2015

If only some years ago tactical or guerilla urbanisms were described happening wherever "residual urban sites and industrial lands have been occupied and converted into new uses by citizens and communities" (Hou, 20l0, 2), today the simple act of "occupying" or "hacking" is perhaps developing towards "disrupting" or overriding old practices of spatial and cultural production. (Zeiger, 20I2) As the historical limitations of participating in the public sphere have already expanded (Hou, 20l0, 4), the significant power of social media as a more inclusive platform has been displayed, compared to traditional methods of sharing information about urban events or planning. Digital communication has increased the accessibility of urban information, and widened its public reach across different ages and social groups.

Finland adopted the use of mobile phones and internet relatively early. The widespread access to technology and the concentration of well-educated urban population in Helsinki, have also contributed in the formation of new types of urbanisms in Helsinki. Social media has enabled an extension to the public sphere, where large enough groups of people can be formed as to give an impression of movements. While many of the fundamentals of social media today can be criticized for their corporate-driven, popularity-based and commercially-biased viewing of the world, for dispersed and traditionally "weak" urban cultures such as experienced in Helsinki, outlets like Facebook have offered new opportunities. Digital technology has made it possible to gather or "hang with friends" despite the grim realities of the Nordic climate conditions that limit the use of traditional public space. It can be said that the critical masses of "followers" enabled by social mediarelated events alone in many recent urban movements in Helsinki have outweighed the traditional planning participation or opinion polling, or any other means of distributing "urban information".

Since the early 2000 s, Helsinki has experienced a strong rise of pop-up events and festivals and to a large part, much of the reach of information of such events has been based on social networks. This type of event economy and hosting activities as consumable urban experiences has worked as a response to a public yearning for urban content. In the hands of the new urban class, these events have also been turned into campaigns and creative practices that have then found support in popular outlets and audiences. (See, Jyrkäs and Luoto, 2014 or Niemi, 20I4) It could also be argued that current activities in Helsinki food culture are not merely about reclaiming public spaces with expectations on food but introducing and trying out new forms and models of production of urban culture, space and practices.

The de-facto role of social media in such developments in Helsinki has been particularly central in especially two cases related to urban food culture that are studied next. Both have already received interest in their early stages from various observations of creative 
urbanisms (Boyer and Hill, 20I I), but considerations on their longer term impacts are worth further discussions.

\section{Pop-Up Case: The Restaurant Day}

The Restaurant Day (Ravintolapäivä) has been one of the most successful urban events to come out of the contemporary Helsinki, eventually becoming "the biggest food event in the world". (Ravintolapäivä, 2016) Started in 20I I as illegally organized low-key event dubbed by the media at the time as "Internet mutiny", it quickly grew into an international brand - and perhaps as such, out of its original setting. The origins of the event were very simple as the first Restaurant Day was run merely as a public Facebook event, orchestrated by three individuals Timo Santala, Antti Tuomola and Olli Sirén, who had teamed up after sharing frustrations of friends and acquaintances over the many regulations of running a restaurant in Helsinki. The three men themselves decided to try and sell food and drinks in the streets from the back of a bike as a protest against the regulations, inviting others to do the same, and enjoy food without restrictions for a day. The call was popular and on May 21 st, $201 \mathrm{I}$, some 45 "restaurants" were opened. They came in all forms and levels of ambition and it seemed that people had a good grasp of what the event was about. Prior to the day, the idea had garnered wide media attention, because of its "guerilla" mentality. While people were accustomed to May Day picnics or sampling market food, the idea of selling food to others without permission seemed somehow radical. People knowingly did something that was technically illegal, yet fun and desirable. Semi-serious speculations were made over what would happen. Would there be arrests or raids by the health inspectors? Would the police intervene? Would people be fined or arrested? In the occasion, newspapers and media would pitch stories on how difficult for an entrepreneur it was to open a restaurant and how debilitating the web of regulations seemed. At the end of the day, no one was arrested. The organizer's own restaurant, selling tapas from a bike, as well as event itself were declared a success. On the second Restaurant Day in August 201 I, 190 restaurants in Finland and some abroad were opened. After two years of gaining momentum, the day held in May 2013 had already gathered over 1,700 one-day restaurants in 30 countries, cementing its popular success and spawning several write-ups in the press. Over the years, restaurants were crafted with all kinds of spatial and conceptual ideas and various levels of professionalism. The event was fixed to run every three months, happening in all seasons and weather conditions, while the figures of pop-up restaurants per event day still remained above I,000. (Restaurant Day, 201 I-16)

Once started, the Restaurant Day quickly became a media darling and also the recipient of many awards, some juries rewarding its merits in promoting food culture, some seeing it as an urban intervention citing its positive influence to communities and contributions to a self-made food culture. In 20II the Ministry of Education and Culture of Finland awarded the organization with the Finland Prize, positioning it on par with notable national artists and cultural figures. The City of Helsinki that had originally advised against the event, started to use its media buzz in its own marketing. The awards and recognition provided unprecedented validation for an event that had sprung from a Facebook activity only some years earlier. 
After a successful run of five years, in May 2016 the Restaurant Day published a statement on their Facebook page, which quoted founder Timo Santala:

While the international food carnival is a great event, it no longer serves the original purpose of Restaurant Day. We wanted to show people that a pop-up restaurant can be opened anywhere and anytime. At this point, an enormous amount of pop-up restaurants are opened worldwide four times a year, but only a handful outside those days. Restaurant Day has never asked - or gotten - any kind of special permits or exceptions to regulations. All pop-up restaurants participating in Restaurant Day can be realized on any given day. Therefore, from now on, every day is Restaurant Day.

Thus, in a timespan of five years, the temporary urban event had become popular enough that it seemed to have served its purpose, in introducing the anti-bureaucratic tool for adding "fun" in to the city it had originated from.

In hindsight, there are many reasons as to why the Restaurant Day became such a phenomenon in the eyes of the great public. A simple reason, evident especially when viewed against the culinary histories and urban culture of Helsinki, was that the event seemed to present a simple solution to difficult questions: how to claim back the city, how to enjoy urban life, how to start-up new vibrant urban practices. It should also be noted that throughout its existence, the event organization has operated without the exchange of money and event sponsors have been turned away. The anti-commercial and anticorporate quality of the Restaurant Day has also been factor in its success, making it both extremely easy and desirable to participate in a people-centered form of urbanism.

Certainly, the directness of action has worked against the frustration of many contemporary Finnish city-dwellers over the regulated and monopolized culinary culture. For the average Helsinkian, the collection of new food experiences and a sense of urban happening have been undoubtedly most welcome.

Furthermore, a sizable portion of all the restaurants that have popped up during the years in Helsinki have been ethnic-themed. Often simple staple dishes from other cultures have made their brief appearance. For some, the day has offered a first opportunity in trying typical dishes from other food cultures and urban settings, for others it has provided the consolation of experiencing a decent specimen of a typical international treat, otherwise unavailable in Helsinki. The popularity of ethnic varieties in the Restaurant Day is telling of an unfulfilled potential diversity of food and cultures in Helsinki, as many cuisines and cultures are currently underrepresented, yet familiar and popular in many world cities. In retrospect, Timo Santala as one of founders has even stated his travel experiences as inspiration for the Restaurant Day, observing a more liberal street culture in Central and Latin America: "I felt that something was missing, that the rules and bureaucracy prevented people's creativity from being unleashed, and a lot of good ideas don't come to light because things are just too difficult or they're not allowed." (Bosworth, 20I5) In short, Restaurant Day's history touches upon many of elements, developments and concerns mentioned in the past chapters on regulations and the Finnish society, and with hindsight, the ultimate success of the event seems an almost self-fulfilling prophecy in these aspects. Here, echoes of past generation's fears of the negative social effects of restaurants, and potential anarchy caused by de-regulation can be heard in the first reactions and media responses. However, the Day's development also provides a case in how its success is connected to accessible modern technology and good understanding of contemporary urban culture and event economy. While first seen as an act of civil 
disobedience, the Restaurant Day was instigated by young urban professionals working in event production, equipped with skills and understanding of how popularity might work in advancing a thought into a public opinion. Utilizing personal connections of creative networks, many elements of the event and its promotion happened quickly, and at a low cost. A fully-fledged website was created for free by people interested in the project, enabling credible and visually pleasing communication with the global audience. A smartphone application was developed with volunteers as well as integration to locationbased services, so that the pop-up restaurants could be pinned on map services. Weaving existing technologies, design and social media into the event has been executed as in any professional project. As such, the Restaurant Day became technologically the most impressive public service of Helsinki, whereas anything provided by the city government at the time, seemed backwards, hindered, and out of touch with what the citizens seemed to be already navigating at ease. The technological success is also a sizable demonstration of how capable normal individuals were in using the tools available, suggesting that almost everyone could start urban movements. This has become well-observed in many recent urban protests. But it can also be suggested that social networks are in any case very much connected with urban foodways today, as they naturally intersect with the "information ways" of contemporary urban life.

As the Restaurant Day was seen maturing, its novelty factor started to naturally stall. Other urban events were taking elements from its operating model and technological prowess and the culture of pop-ups has in general become more mainstream. Still, its legacy over contemporary Finnish urbanism and urban food culture remains undeniable. Undeniably, for Helsinki, the Restaurant Day remains one of the first examples of how contemporary urban movements could be started, orchestrated, and designed, and how added value in urban life could be produced through forms of low-threshold activism.

\section{Mobile Case: The Coffee Truck and the Espresso Bike}

Signifying how detailed the clashes between regulations and transforming food culture have become, are some specific cases related to mobile devices and structures for setting up a food establishments. The most famous example in Helsinki in a particular era was arguably the Camionette coffee truck, a vintage van first acquired and restored by a young entrepreneur Tio Tikka, with the aim of selling coffee and crepes on the streets 24 hours a day. He had seen similar trucks elsewhere in Europe and saw the idea as sympathetic novelty if brought in Helsinki, lacking anything of the sort. After spending time and money in the project and with initial positive talks with the city, Tikka received information that his sales permit was denied. The Public Works department had stated that his mobile kiosk would cause negative effects in the "city image" (kaupunkikuva) and "cause disturbances for traffic".

After the negative response, the entrepreneur decided not to complain about the decision to the Public Works department but instead to make his case public, using the tools he had available. After starting a campaign on Facebook - a means available to any young Helsinkian - in matter of days the project page had gathered over 10,000 supporters, who unanimously agreed that the city was being absurd in its claims and the coffee truck was instead exactly the kind of activity that was missing from the "city image". The success prompted also the traditional media to inquire responses from politicians in the city 
council, who could mostly only concur, with promises to look into the matter. Tikka's campaign continued to post photos to the public of his coffee truck parked in various spots in Helsinki streets, introducing a stark comparison with the existing, undeniably uglylooking but purportedly regulated streetscape. Facing elections, and the overwhelming public opinion, the political pressure ultimately turned around the decision and the truck started operating at a fixed location in the summer of $201 \mathrm{I}$.

The reasons first cited for denying permits for mobile kiosks by the city resembled quickly formed panic reactions as the issue was faced for the first time in the modern era. Historically, unregulated food stalls had been part of urban Helsinki in the early $20^{\text {th }}$ century, but had disappeared by the 1960s with expanding sanitary regulations. It seemed as though over the years the city had comfortably been adding regulations, with the thought that it was according to the people's will. When confronted, worries for the cityscape and traffic arrangements served as scapegoats for a lack of new strategy. However, after the initial shock and a certain awakening to the public opinion, in the following summer the city had already started to overhaul its strategy for food trucks even though the concept was entirely unknown in contemporary Helsinki. Unlike in many American cities, for instance, there was no existing framework for operating such businesses and many city officials would truly be unfamiliar with the concept, without knowledge or examples on how food trucks could be managed and what they would look like. A “kiosk-on-wheels” didn't even exist as a category for food permits and there was no expertise in evaluating such projects.

Since early 2014, the Public Works department has come to introduce "agile kiosk activities" (ketterä kioskitoiminta) into their latest suggestion of revised kiosk regulations. Today, some specific areas in central Helsinki are designated for food and coffee trucks, whereas everywhere else agile kiosks can be operated quite freely. In the instructions, a mobile kiosk carries the definition "registered vehicle or carriage." At first, with hopes of selling coffee from a bicycle equipped with gas-powered espresso makers, some entrepreneurs were left disappointed as bikes would not fall under the definition of registered vehicles, leaving such sales to be regulated by the stricter national food legislation. Again, such novel ideas of entrepreneurs were almost thwarted simply because they could not have been anticipated by the officials. Today, selling coffee from a mobile bike in Helsinki requires no permit, but the challenges are more related to establishing a culture of mobile kiosks, beyond the idea of doing so based on imported examples.

\section{Conflicts, Policy Changes and Legacy}

What remains as the most interesting outcome of these perhaps most famous cases in recent events in urban food culture of Helsinki - the Restaurant Day and the coffee truck - is their quick effect on city policies. In both cases the conflicts arising from old regulations and new endeavors became escalated in social media to such an extent that denying the will of the public change would have been politically impossible. For the average Helsinki resident craving for more urban food variety in the city and less regulation over urban opportunities, the conflict between the views from the administration and the prospect of missing out on yet another urban experience quickly began to dominate the discussion. Today, the set-up of new trendy urban projects similar to urban agriculture, activism, reclaiming or reusing and appropriating public space tends 
to align, similarly positioned as the opposite of bureaucratic sounding policies and planning. Bringing regulations under public examination has provided a precedence for social media commentators, news outlets and different organizations to take a stance in their evaluation of any new developments in the urbanism front.

What is also remarkable is that the Restaurant Day has today become an official anomaly within the city management culture. On multiple fronts city departments have listed the day as a special item in their policies. Today, the Public Works Department of Helsinki publicly states it "doesn't want to hinder the popular event" offering only advice for restaurant keepers on tidiness. The city's Environment Centre, responsible for health inspections today lists a specific chapter on the Restaurant Day type of events on their website, stating that sales of food and beverages is allowed during the one-day festival and no hygiene requirements are imposed during the event. The Centre also recognizes popup restaurants in general in its statement, offering further advice in their organizing. This change of tone has also been visible in statements made by the police authority and Valvira, the National Supervisory Authority for Welfare and Health. In 20 I , the first year of the Restaurant Day event, the authorities co-released statements reminding that the sales of alcohol remained prohibited outside actual restaurants. The wordings again echoed of a past era fears of "unlawful sales", "disturbances" and even "societal problems." On the second year the same statement had transformed into a simple information bulletin for the event participants. On the third year, no further statements were given. Such processes are telling of how Finnish officials seemed at first to be hiding behind citing rules, but with continuous positive public feedback, they ultimately took a more active role in enabling events that were proven to work. In the case of the coffee truck, the real change of policies and views came from the introduction of the novel concept of mobile vending platforms, and the respective missing regulations.

\section{Aesthetical and Spatial Considerations}

For urban Helsinki, new lines of thinking and evolving city governance have happened roughly in two fronts: what has been designed and produced as cultural production, and what has been regulated as urban activities. With increasing interest in food and contemporary tactical urbanisms, the aesthetic appeal and the spatial production of almost any new creative project, automatically seems to speak to current urban cultural consumers, whereas the regulations set by city officials have seemed mostly to gather less enthusiasm and face even hostile campaigns, sometimes unfairly.

This division becomes visible, for instance, in comparing aesthetics produced by different sets of rules. From the beginning of 2014, Helsinki introduced new instructions for outdoor serving areas (terassiohjeet). While the aim of the instructions booklet was to provide clear rules for what is visually allowed and what is demanded for restaurant terraces in the city, taking into account different legislations and accessibility requirements, the instructions were met with anger from the restaurant industry, escalating to threats of removing all existing terraces as a protest because of high costs to the restaurants for meeting the new standards. At the same time, on the other end of the spectrum there would exist a small summer café run perfectly legally from a metal container and hosting a free-form lounge terrace in Kalasatama, an old harbor area waiting for redevelopment. 
The difference between these two aesthetics is that former is seen as permanent, whereas the latter is a designated temporary use.

There remain some unresolved problems in this division. On one hand, undoubtedly for contemporary Helsinki, events and pop-ups have already become a method for contemporary place-making. As a whole they have become the bars, clubs, restaurants, shops, galleries and workshops that have been missing from the cityscape, often taking advantage of the cross-over potential of contemporary urban space, street art and of course, their own particular concepts. In relation to urban food culture, they have become collaborative venues with custom made identities and products, incorporating local talent and production capabilities, fostering an ecosystem of food-related events, rather than displays or offerings of food itself.

These changes are interesting in the sense that, in the realm of traditional urban planning and design, it has been customary to merely wish for things to happen and to fill renderings with people, cafés, exhibitions, parks and multi-use open spaces. It has been easy to declare urban areas as citizen plazas or stages for all kinds of public use. But if thought as contemporary practices, the difference between producing a pop-up venue and wishing for things to pop up in traditional urban design, is that temporary venues have often successfully overruled the original design intentions. In Helsinki, it could be said that food pop-ups in particular have been able to take whatever is wrong, and use it as a starting point for desirable urban culture.

It might also be tempting to see examples of the "reckless" behavior of many pop-ups as purely experimental, and of use only in the special context of festivals and happenings, where the temporariness ensures us that there is no need for concern even though rules and regulations are violated. But if temporariness might become one of the rules, then at the very conceptual level, events like Restaurant Day also signify a shift towards a posttemporary city, where simply a curated or designed flow of urban events happens, and cultural content and public culture gets produced. Of course, at the same time, traditional frameworks, urban foodways and other forms of production should be maintained, as the backlash effect of gentrification or producing overtly engineered events is equally subjected to public opinion as the original popularity of pop-ups.

\section{Further Developments and Strategies}

Ultimately, the recent developments in Helsinki have not only consisted of isolated projects successful in their own right. Instead, what has happened on the strategic level of planning is that food has been put into the programming of the city, and used as a means of achieving development goals. The role of Restaurant Day in this development appears as a significant catalyst. But regardless of the event's popular note, it proves that the policy changes forced down by previous examples of developing urban culture have had a deeper effect on the thinking of what constitutes as strategic design for cities.

While evaluating where the current development is heading is still a work in progress, much of the activities that have been started after and during the Restaurant Day have inevitably benefitted from its working model and the established public and political momentum. As pop-up restaurants or any other events as such are not anymore new - in fact they've become also ordinary and mainstream - the following phase of development in urban contemporary food culture of Helsinki seems to be a shift towards a more 
professional outlook on the subject. Continuous pop-up production has produced experts in the related technical solutions, content, cultural management, consulting and research everything required in generating urban events. However, perhaps due to likeability and the positivity of food, many of these developments have been food-centric and building on the "post-pop-up" atmosphere of urban Helsinki.

As an example, in March 20I4, a new Streat Helsinki event launched street kitchens and block parties in central Helsinki for 20,000 visitors. During two days the event provided sampling of a variety of food created specifically or made available during the event, gathering "exhibitors" from famed restaurants and well-known food operators, from Finland and abroad. It received wide sponsorship from companies and organizations that saw image value in cooperation with the urban food theme, already popular in Helsinki. Taking the event a step further was a miniature conference in the form of food talks that gathered well-known pioneers in the street food scene, who have independently created success stories of food festivals, sandwich trucks, temporary culinary gatherings, in combination with representatives from cities with progressive street food policies and food strategies. However, instead of activists or social media campaigners, the event was crafted by City of Helsinki's Food Culture Strategy team with partners in both public and private sectors. This well exemplifies the current state of Helsinki's urban food culture, where the creation of street food carnival as an event that captures the essence of popular contemporary urbanism and also develops into an international platform, is in essence an urban project that spans into producing, marketing, branding and design, further labeling the city as a contemporary culinary hub, listing "500 conference guests, countless new contacts, new ideas and initiatives" as its achievements.

In a rather poetic turn of events, the Food Culture Strategy originally laid out as a project for 2009-2012, eventually hired Restaurant Day founder Timo Santala as its head in 2015. Today, the strategy unit has at least seemingly become a facilitator in all-around activities governing food and the city. Operating under a city unit called Tukkutori (named after a traditional local wholesale area), the strategy has come to include both the new events and traditional forms of food sales and markets. New start-up concepts include Teurastamo (Butchery) that has been developed as a more permanent food hub hosting restaurants, events and activities, following examples and popularity laid out by pop-up activities. Questions remain whether the adoption of these strategies by the city government will in the long term be able to innovate and keep up with the public demand, or will they also become stagnated as their more regulatory predecessors were.

\section{Conclusions}

The recent fast cycle of culinary culture related developments in Helsinki reflects an ongoing change in the relationship with food and urban space. The path from organizing homegrown illegal guerilla-restaurants to swift policy changes, popular approval and incorporating tactical urbanism tools in city strategy-building, seems to suggest that Helsinki - as the central scene for Finnish urban life is perhaps experiencing a wider change in the valuation of urban lifestyle with kinship towards larger and more international cities. Food culture and urban foodways are changing in accordance with several other new urban signalers, such as the emergence of event economy or smart solutions. Examples of start-up style technological development of events and models of cultural production, such 
as pitching talks or market fair platforms suggest some likeness to the American contemporary urban development rather than the Central European tradition concerning food and the city.

The fact that much of the current Helsinki activities have circled around food, is perhaps partly accidental, but also following a global trend, as food touches everyone in cities and matters related to its production and quality have also become a worldwide phenomenon. In the case of Helsinki, food events instead of art fairs, biennials or fashion weeks, have served as platform for achieving fast changes in the urban culture and space, available to a large number of people. Food has become an easy and benevolent way of expressing expanded urban identities, allowing also culturally more diverse urban displays than what perhaps has been the case previously. As a result, the general Finnish ruokakulttuuri has quickly gone through changes that can partly be attributed to the urban food phenomenon, such as many deregulatory efforts and a surge in restaurant eating, affecting also coming generations who will undoubtedly have different conceptions about food and drink than their parents. This observation alone is already a clear change that has happened during a single generation of Finnish urban dwellers.

Ultimately, events such as the Restaurant Day have provided a framework where creative participation and even social inclusion have taken place. Cases such as the Camionette coffee truck have made city governance more perceptible to ideas and changes in regulatory culture. A combination of popular online platforms such as Facebook, increased closeness with the all-around contemporary urban culture and trends as well as poignancy in aesthetic and technical production, has contributed to the success of urban food events in Helsinki. Sense of empowerment through technology, the explicit and direct public experiences of stronger and more varied urban cultures, have already become more valuable to the general public than observing planning regulations created in the past with only societal well-being and ideological modernist state-building in mind. Risks in this development relate to heavy reliance on events and happenings as a source of liveliness and urban experiences, as well as the relationship of perceived event popularity in social media vis-à-vis the publicness or true social inclusivity of such practices.

So far, the positive aspects of the urban food culture development have been welcomed by the both the Helsinki residents and the city officials and a new wave of planning and management has been formulating as a result. The development and urban experiments in food culture have clearly offered desirable remedies for a particular longing for more urban and more international lifestyles in Helsinki. In essence, urban foodways have become forms of urbanism and urban practices that are familiar to today's Helsinkians. The popularity of "guerilla" food culture or grassroots movements has also driven the institutionalization of urban food, as has been signified by adopting of food strategies and design concepts. What remains to be seen, is how the current development will be positioned beyond the urban cultural shift, and whether it will induce lasting changes, or even becoming an exportable cultural product or a true import replacement for the Helsinki urban setting. What is clear already, is that Helsinki has - with gusto - taken a path of convergence to urban event tactics, food strategies, planning and design. Following these developments in the future should provide an interesting view on how urban foodways may shape current and upcoming urbanisms, and the makings of Helsinki streets. 


\section{References}

Boyer, B and Hill D. (20/3). Brickstarter. R. Hyde (Ed.). Helsinki: Sitra, Finnish Innovation Fund.

Boyer, B. and Hill, D. (20I I). Helsinki Street Eats. Helsinki: Sitra, Finnish Innovation Fund.

Bossworth, M. (20I5, March 4). Helsinki: trail of the unexpected. High Life. Retrieved I August, 2016, from http://highlife.ba.com/articles/helsinki-restaurant-day

Camionette - Café et Crêpes. (20II). In Facebook [Café]. Retrieved May I2, 20I4, from http://www.facebook.com/kahviauto

City of Helsinki Culinary Culture Strategy. (2009). Helsinki: City of Helsinki.

Comparative price levels for food, beverages and tobacco. (2016) Eurostat. Retrieved August I, 2016, from http://ec.europa.eu/eurostat/statisticsexplained/index.php/Comparative_price_levels_for_food,_beverages_and_tobacco

Erjansola, J. \& Hiekkavuo, A. Eds. (2016) Population with foreign background in Helsinki 2015. Statistics, 2016:2. Helsinki, City of Helsinki Urban Facts.

Every Day Is Restaurant Day Now. (2016, May 18).[Press release]. Retrieved August 8, 2016, from https://www.facebook.com/notes/restaurant-day/every-day-is-restaurant-daynow/I0568/208773/043

Hauck-Lawson, A. and Deutsch J. (2008). Gastropolis : Food and New York City. New York, NY, USA: Columbia University Press.

Helsingin ruokakulttuuristrategian vuosikatsaus. (201 I). Helsinki: Tukkutori, City of Helsinki.

Helsingin Tukkutorin toimintakertomus 2013. (2014). Helsinki: Tukkutori, City of Helsinki.

Helsinki - Tallinn. Facts and Figures 20 I4. (20I4). Helsinki: City of Helsinki Urban Facts. Tallinn: The Development Service of Tallinn City Office.

Hou, J. (20I0). Insurgent Public Space : Guerrilla Urbanism and the Remaking of Contemporary Cities. Routledge. Retrieved 22 April 20 I4, from http://www.myilibrary.com?!I =2586I0

Jyrkäs, P. and Luoto, K. (Eds.). (20I4) Opas kaupunkiaktivismiin - uutta kaupunkikulttuuria luomaan. Helsinki: Prototype Helsinki.

Food trucks. (2016). Helsinki: Public Works Department, City of Helsinki. Retrieved August 8, 2016, from http://www.hel.fi/www/hkr/en/permits/kiosks sales spots/food trucks

Kokkinen, A. (2012) Miten Suomi nousi köyhyydestä? Tieto \& trendit, I/20I2. Helsinki: Statistics Finland.

Kolbe, L. (2005) Kotimaista ruoka- ja juomakulttuuria. Suomalaisten symbolit. Ed. Tero Halonen \& Laura Aro. Jyväskylä: Atena.

Laakso, S. (20/2) Helsingin seudun ja Helsingin väestökehitys - Toteutunut väestönkasvu ja projektiot vuoteen 2050. Helsingin kaupunkisuunnitteluviraston yleissuunnitteluosaston selvityksiä 20I2:3. Helsinki: City Planning Department, City of Helsinki.

Levi, J. (2015) Ethical Gastronomy: Organic Food, Markets and Marketing. Markets: Proceedings of the Oxford Symposium on Food \& Cookery 20 I4, ed. Mark McWilliams, 232-240. Totnes, Devon: Prospect Books.

Lindblom, T. \& Mustonen, P. (20I4) Ruokamaku ja legitiimit ruokatyypit helsinkiläisten 25-44 vuotiaiden keskuudessa. Kvartti I/20I4.

Lindblom, T. \& Mustonen, P. (20।6) Kantakaupungissa asuu tyytyväisiä lapsiperheitä. Kyselytutkimus asumistyytyväisyydestä ja asumisvalinnoista Helsingissä. Kvartti I/2016.

Lisää kaupunkia Helsinkiin. (20I2) In Facebook [Group]. Retrieved May 12, 20I4, from https://www.facebook.com/groups/ /840850736I7/

Nelimarkka, M. (20I4) Ravintolapäivä karnevalisoi syömisen. Retrieved May 12, 20I4, from http://www.visithelsinki.fi/majoitu-ja-nauti/syo/ravintolapaiva-karnevalisoi-syomisen

Nevalainen, L. (2013) Torit ja kauppiaat. Keittoja, vellejä, muhennoksia: Työläisten ruokailu teollistuvassa Suomessa. Helsinki: Hotel and Restaurant Museum. Retrieved I August, 2016, from http://www.tyovaenruokailu.fi/p/torit-ja-kauppiaat-2_I.html 
Niemi, J. Starting Succesful Urban Movements. Steep Insights I/20I4 · 28 February 20I4. Retrieved May 12, 20I4, from http://www.steep.fi/research/2014/02/starting-successful-urban-movements/

Peltoniemi, A. (20I3). Ruokakorin hintakehitys. Kuluttajatutkimuskeskus, työselosteita ja esitelmiä I44 - 2013. Helsinki: Consumer Society Research Centre, University of Helsinki.

Poliisi varoittaa Ravintolapäiviä: Alkoholin myynnistä ei selviä rikesakoilla. (20I2, May 14). Iltasanomat. Retrieved May 12, 20I4, from http://www.iltasanomat.fi/kotimaa/artI288469043050.html

Pop up -ravintoloissa ei saa myydä tai anniskella alkoholia ilman lupaa. (201 I, November 9) [Press release]. Retrieved May 12, 20I4, from http://www.valvira.fi/valvira/lehdistotiedotteet/pop_up_ravintoloissa_ei_saa_myyda_tai_anniskella_alkoholia_ilman_lupaa

Ravintolapäivä 2014. (2014). [Website]. Retrieved May 12, 2014, from http://www.hel.fi/hki/hkr/fi/ajankohtaista/ravintolapaiva_20I4

Restaurant Day. (20II) [Website]. Retrieved May 12, 20I4, from http://www.restaurantday.org/en/info/about/

Richards, Greg \& Palmer, Robert. (2010). Eventful cities: cultural management and urban revitalisation. [Books24x7 version] Retrieved May 12, 2014, from http://common.books24x7.com.easyaccess I.lib.cuhk.edu.hk/toc.aspx?bookid=40I54

Ruokakulttuuristrategian raportti. (20I2). Helsinki: City of Helsinki.

Ruokamyynnin sääntely kypsytti Ravintolapäivän. (20I I, November 9). Helsingin Uutiset. Retrieved from http://www.helsinginuutiset.fi/artikkeli/79069-ruokamyynnin-saantely-kypsyttiravintolapaivan

Ruokatieto / Finfood - Finnish Food Information. (2016). Ravintolaelämä käynnistyy keisarikunnassa. Retrieved August 8, 2016, from http://www.ruokatieto.fi/ruokakulttuuri/gastronominensuomi/ruokakulttuurin-muutos-helsingissa/ravintolaelama-kaynnistyy-keisarikunnassa

Salomaa, M. (20I3, December 13). Helsinki heltyi: Kahvila-autoille vihreää valoa. Helsingin Sanomat. Retrieved May 12, from www.hs.fi/kaupunki/a I 386476562992

Sillanpää, M. (2002). Säännöstelty huvi: Suomalainen ravintola 1900-luvulla. Helsinki: Finnish Literature Society.

Street Food Circled the Helsinki City Hall. Streat Helsinki Exceeded All Expectations. (20I4, March 26). [Press release]. Retrieved, May 12, 2014, from http://streathelsinki.com/press

Tani, S. (1995) Elokuvien maaseutu suomalaisena mielenmaisemana. Maaseudun uusi aika : maaseutututkimuksen ja -politiikan aikakauslehti. Vol. 3, No. 2. 38-47.

Taussig, M. (2016) Let Us Now Praise Famous Seeds. L'Internationale. Retrieved August 8, 20I6, from http://www.internationaleonline.org/research/politics_of_life_and_death/72_let_us_now_praise famous seeds

Terassiohjeet Helsingissä. Ulkotarjoiluun käytettävien katuterassien ohjeistus I.I.20I4 alkaen. (20I3). Helsinki: Public Works Department, City of Helsinki.

Verkkokapina tuo Suomeen yli 40 piraattiravintolaa. (20II, May 19). Kauppalehti. Retrieved May I2, 20I4, from http://www.kauppalehti.fi/etusivu/verkkokapina+tuo+suomeen+yli+40+piraattiravintolaa/201 I05 75603

Zeiger, M. (201I, September) The Interventionist's Toolkit: 3, Our Cities, Ourselves. Places Journal. Retrieved August 5, 2016, from https://placesjournal.org/article/the-interventionists-toolkit-ourcities-ourselves

Zeiger, M. (2012, March 27) The Interventionist's Toolkit: 4, Project, Map, Occupy. Places Journal. Retrieved May 12, 2014, from https://places.designobserver.com/feature/the-interventioniststoolkit-part-4/32918/ 